\title{
ANALYSIS OF THE EFFECTS OF OVERLOADING ON THE AGE OF THE TOLL ROAD CASE STUDY TANGERANG-MERAK KM 72 S/D KM 77
}

\author{
Andri, Irfan Rifai \\ Faculty of Engineering \\ University Mercu Buana Jakarta, Indonesia \\ andrirfan@yahoo.com \\ Raflo, Barus \\ Faculty of Engineering \\ University Mercu Buana Jakarta, Indonesia \\ raflobarus@gmail.com
}

\begin{abstract}
Economic growth that occurred in Indonesia requires adequate infrastructure. The large number of infrastructure which found in Indonesia is not accompanied by the compliance level of infrastructure users, the number of violations that occur causes a decrease in the life of a road. Overloading does not only causes road damage but also impacts on the lack of road safety. Therefore, research and analysis are carried out to find out how much influence is given by the overload on a road, in this case the age of the plan. The method which used to find out how big the impact of a normal charge is with remaining life, which is to compare the age of a normal load plan with overload. By this method it is necessary to know the Vehicle Damage Factor (VDF) which will later be used to find the cumulative ESAL of each vehicle condition, then with the cumulative ESAL that occurs can know the remaining life of a road. From the conducted analysis result, it was found that each vehicles had an increase in vehicle damage factor (VDF), as well as the cumulative ESAL that was previously planned to receive cumulative ESAL in the amount of 20.602.172 with the cumulative overloading of ESAL received to 284.426.068, due to the charge causing a decrease in remaining life is 4 years 9 months or decreased by $24 \%$.
\end{abstract}

Keywords : Overload, ESAL, Remaining Life

\section{INTRODUCTION}

Indonesia as one of the countries with the highest economic growth. The Central Statistics Agency said Indonesia's economic growth was at 5.07\%, with the amount of economic growth having to be supported by adequate infrastructure, one of the important infrastructures was roads.

Roads are a very important infrastructure for mobilizing in land transportation, roads are also one of the driving forces of the economy and also as an infrastructure of community activities in various development sectors of the economic, social, political, cultural and security sectors. In addition, the road also provides a good solution for the smooth flow of traffic which has an impact on the smooth delivery of one region to another.

Large-scale road construction by the government is not followed by compliance with logistical transport providers, many logistical transport service providers carry loads exceeding the load limits set by the government. Director General of Land Transportation of the Ministry of Transportation (Kemenhub), Budi Setiyadi, said the number of violators reached $81.07 \%$. The figure was recorded during the 14-day supervision period of July 8-22 2019 in 21 Implementing Vehicle Weighing Unit (UPPKB) or weighbridge.

PT. Jasa Marga TBK said that it suffered a loss of around 1.5 trillion Rupiah as a result of vehicles carrying overloads and over-dimensions. These losses include road repair costs, consisting of $40 \%$ routine repairs and $60 \%$ road reconstruction. Other effects of overloading include reduced levels of driving safety, congestion and faster damage to vehicle parts. Basically the road will experience a decrease in structural quality in accordance with the 
increase in the life of the road, especially if it is passed by vehicles exceeding the provisions, with the number of vehicles overloading very influential in reducing the age of pavement services (Ojha, 2018).

Likewise, the Tangerang-Merak Toll Road, which is the only toll road that connects the Jabodetabek area with the Merak Port, is inseparable from the violation of the vehicle's cargo. Therefore PT. Marga Mandala Sakti as the manager of the Tangerang-Merak Toll Road placed Weight In Motion (WIM) tools on some of their toll gates, the function of Weight In Motion (WIM) is to measure the load of vehicles that will enter the Tangerang-Merak Toll Road section. Road pavement damage that occurs is a combination of several interrelated factors. By considering the current conditions, the author wants to conduct research under the title "ANALYSIS OF THE EFFECTS OF OVERLOADING ON THE AGE OF THE TOLL ROAD CASE STUDY TANGERANG-MERAK KM 72 S/D KM 77"

\section{RESEARCH METHODOLOGY}

The method of data analysis in this study refers to the AASHTO Method by calculating the reduction in the percentage of age in each year so that a comparison between plans and actual conditions is found.

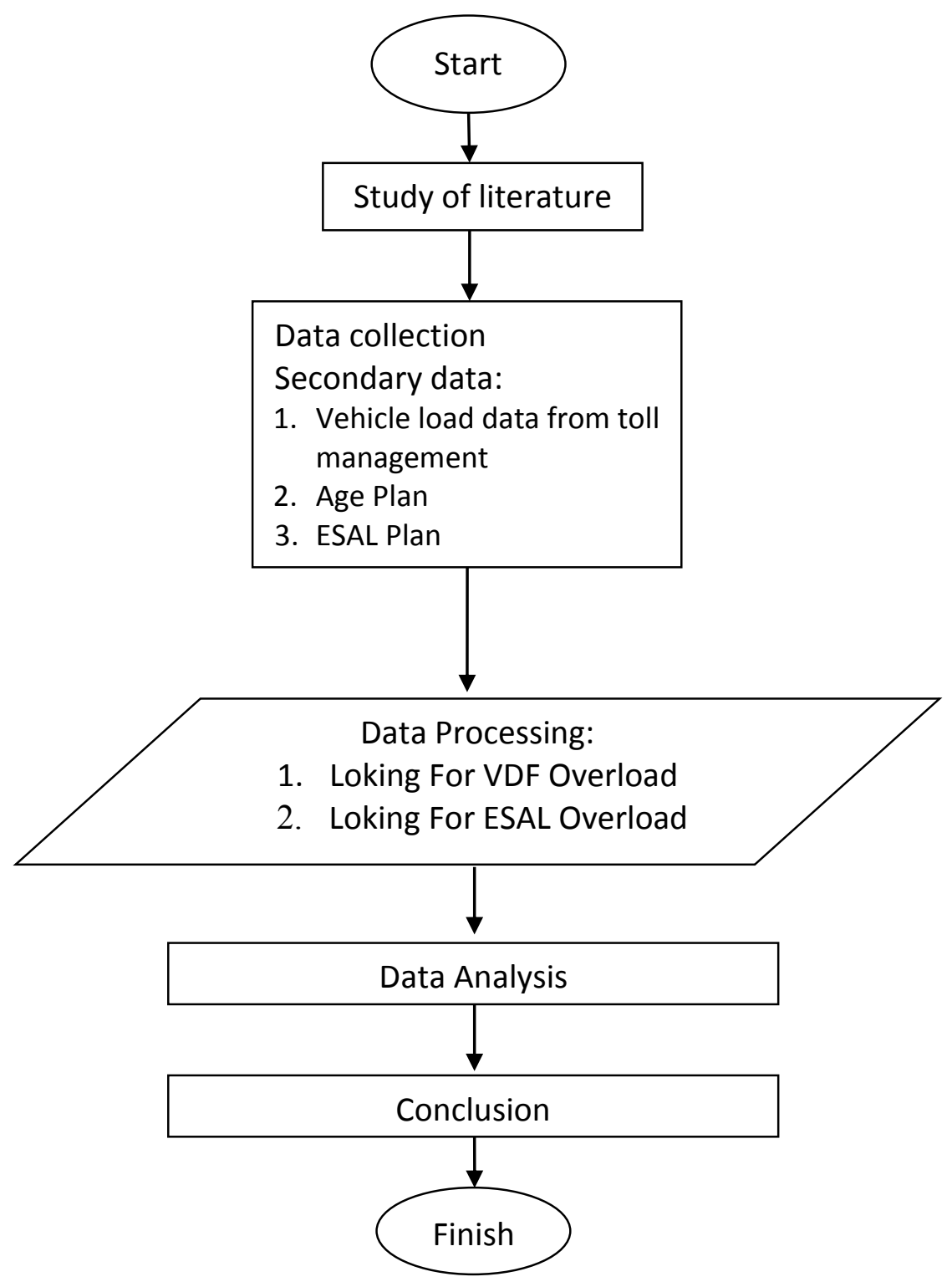


The order of analysis as follows:

1. Single Axle Load

At this stage the primary data in the form of traffic data is converted to an equivalent number using the standard source load equation.

2. Vehicle Damage Factor

At this stage, single axle load become vehicle damage factor by adding up all the single axle load numbers of each vehicle.

3. Equivalent Single Axle Load

Then the number of vehicle damage factor is entered ESAL equation, so that it can be ESAL for the year.

4. Look for Influence Overload

At this stage, the ESAL obtained is compared with the ESAL of the planned load, so that the effect of the overload on the life of the plan is found.

5. Conclusion

At this stage the authors provide conclusions from the results of the analysis carried out so that conclusions are found, then the authors also provide the necessary advice.

\section{Research Site}

The research site reviewed was the Tangerang toll road section to Merak. Precisely on the Section of the Road between the West Serang Toll Gate to the East Serang Toll Gate.

Figure 1. Research Site

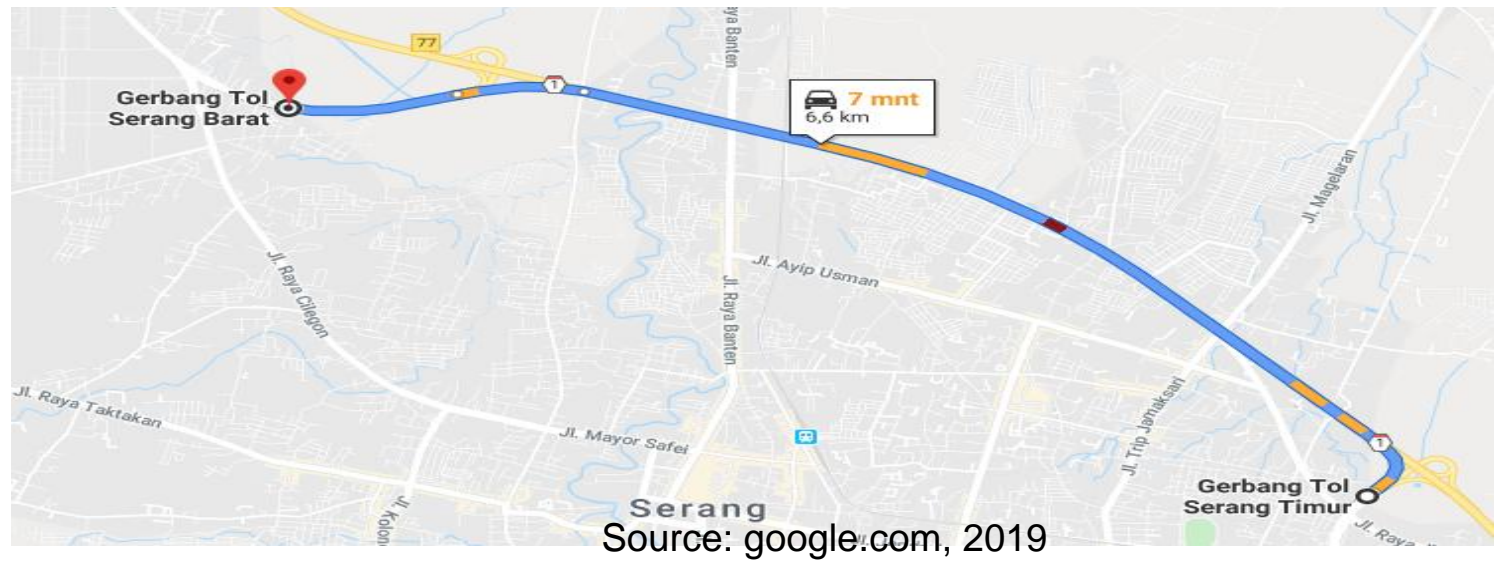

At this toll gate, the Weight In Motoin (WIM) engine was located, which used as a tool to measure the vehicle load that will be used to search for ESALs from every vehicle that passes.

\section{RESULTS AND DISCUSSIONS}

Data

Supporting data in this final project is the Average Daily Cross (LHR) data and the Load data of each vehicle taken from the Weight In Motion (WIM) equipment located at the Serang Barat Toll Gate. 
Average Daily Trafic

The results of the average daily traffic of Serang Timur to Serang Barat toll gates, can be seen in the table below:

Table 1. Average Daily Trafic of Serang Barat and Serang Timur toll gates

source : PT. Marga

\begin{tabular}{|c|c|c|c|}
\hline \multirow{2}{*}{$\begin{array}{l}\text { Class of } \\
\text { Vehicle }\end{array}$} & \multicolumn{3}{|c|}{ Years } \\
\cline { 2 - 4 } & 2017 & 2018 & 2019 \\
\hline Gol 1 & 29,273 & 29,830 & 29,956 \\
\hline Gol 2 & 7,348 & 7,569 & 6,760 \\
\hline Gol 3 & 5,723 & 5,845 & 5,425 \\
\hline Gol 4 & 1,188 & 1,287 & 1,136 \\
\hline Gol 5 & 1,235 & 1,400 & 1,221 \\
\hline
\end{tabular}

Mandala Sakti, 2019

Load Vehicle

For vehicle overloaded data, it can be seen in the table below:

Table 2. The number of vehicle overload and vehicle load

\begin{tabular}{|c|c|c|}
\hline Configuration & Overload Vehicle & Vehicle Load (ton) \\
\hline $1-1$ & 2890 & 4,25 \\
\hline $1-2$ & 641 & 24,2 \\
\hline $1-2.2$ & 1362 & 32,72 \\
\hline $1.2-2.2$ & 935 & 36 \\
\hline $1.2 .2-2.2$ & 836 & 54,5 \\
\hline $1-2.2-2.2 .2$ & 952 & 53.6 \\
\hline
\end{tabular}

source : PT. Marga Mandala Sakti, 2019

Vehicle Damage Factor (VDF)

Vehicle Damage Factor can be seen in the tables below:

\begin{tabular}{|c|c|c|}
\hline Configuration & Load & VDF \\
\hline $1-1$ & 2 & 0.0004511 \\
\hline $1-2$ & 18,3 & 0.70300735 \\
\hline $1-2.2$ & 25 & 2.74157251 \\
\hline $1.2-2.2$ & 31,4 & 3.90832713 \\
\hline 1.2.2-2.2 & 40 & 4.13321645 \\
\hline 1.2.2-2.2.2 & 46 & 4.51761419 \\
\hline
\end{tabular}

Source: Data in research, 2020 
Table 4. VDF Overload Vehicle

\begin{tabular}{|c|c|c|}
\hline Configuration & Load & VDF \\
\hline $1-1$ & 4,25 & 0,0092 \\
\hline $1-2$ & 24,2 & 2,1499 \\
\hline $1-2.2$ & 32,72 & 8,0444 \\
\hline $1.2-2.2$ & 36 & 6,7528 \\
\hline $1.2 .2-2.2$ & 54,5 & 11,7252 \\
\hline $1.2 .2-2.2 .2$ & 53,6 & 8,3279 \\
\hline
\end{tabular}

Source: Data in research, 2020

Cumulative ESAL

The cumulative ESAL is sought by adding up the ESALs received by a road every year so that it will be known that ESALs are received by a road in the planned time unit.

a. Cumulative Normal Load

For Cumulative Normal Load, it can be seen in the tables below:

Table 5. Cumulative ESAL Normal Load

\begin{tabular}{|c|c|c|c|}
\hline Year Line & Year & ESAL & Cumulative ESAL \\
\hline 0 & 2019 & 0 & 0 \\
\hline 1 & 2020 & 8.229 .766 & 8.229 .766 \\
\hline 2 & 2021 & 8.388 .355 & 16.618 .121 \\
\hline 3 & 2022 & 8.552 .415 & 25.170 .536 \\
\hline 4 & 2023 & 8.722 .223 & 33.892 .759 \\
\hline 5 & 2024 & 8.898 .072 & 42.790 .831 \\
\hline 6 & 2025 & 9.080 .274 & 51.871 .105 \\
\hline 7 & 2026 & 9.269 .157 & 61.140 .262 \\
\hline 8 & 2027 & 9.465 .069 & 70.605 .331 \\
\hline 9 & 2028 & 9.668 .378 & 80.273 .709 \\
\hline 10 & 2029 & 9.879 .476 & 90.153 .185 \\
\hline 11 & 2030 & 10.098 .776 & 100.251 .961 \\
\hline 12 & 2031 & 10.326 .717 & 110.578 .678 \\
\hline 13 & 2032 & 10.563 .763 & 121.142 .441 \\
\hline 14 & 2033 & 10.810 .407 & 131.952 .848 \\
\hline 15 & 2034 & 11.067 .170 & 143.020 .018 \\
\hline 16 & 2035 & 11.334 .607 & 154.354 .625 \\
\hline 17 & 2036 & 11.613 .303 & 165.967 .928 \\
\hline 18 & 2037 & 11.903 .881 & 177.871 .809 \\
\hline 19 & 2038 & 12.207 .001 & 190.078 .810 \\
\hline 20 & 2039 & 12.523 .362 & 202.602 .172 \\
\hline \multicolumn{3}{|c|}{ Source: Data in research, 2020 } \\
\hline
\end{tabular}


b. Cumulative Overload

Cumulative Overload can be seen in the table below:

Table 6. Cumulative ESAL Overload

\begin{tabular}{|c|c|c|c|}
\hline Year Line & Year & ESAL & Cumulative ESAL \\
\hline 0 & 2019 & 0 & 0 \\
\hline 1 & 2020 & 11.165 .330 & 11.165 .330 \\
\hline 2 & 2021 & 11.415 .050 & 22.580 .380 \\
\hline 3 & 2022 & 11.674 .245 & 34.254 .625 \\
\hline 4 & 2023 & 11.943 .405 & 46.198 .030 \\
\hline 5 & 2024 & 12.223 .043 & 58.421 .073 \\
\hline 6 & 2025 & 12.513 .705 & 70.934 .778 \\
\hline 7 & 2026 & 12.815 .965 & 83.750 .743 \\
\hline 8 & 2027 & 13.130 .435 & 96.881 .178 \\
\hline 9 & 2028 & 13.457 .760 & 110.338 .938 \\
\hline 10 & 2029 & 13.798 .621 & 124.137 .559 \\
\hline 11 & 2030 & 14.153 .746 & 138.291 .305 \\
\hline 12 & 2031 & 14.523 .896 & 152.815 .201 \\
\hline 13 & 2032 & 14.909 .881 & 167.725 .082 \\
\hline 14 & 2033 & 15.312 .565 & 183.037 .647 \\
\hline 15 & 2034 & 15.732 .855 & 198.770 .502 \\
\hline 16 & 2035 & 16.171 .712 & 214.942 .214 \\
\hline 17 & 2036 & 16.630 .162 & 231.572 .376 \\
\hline 18 & 2037 & 17.109 .282 & 248.681 .658 \\
\hline 19 & 2038 & 17.610 .219 & 266.291 .877 \\
\hline 20 & 2039 & 18.134 .191 & 284.426 .068 \\
\hline \multicolumn{3}{|c|}{ Source: Data in research, 2020} \\
\hline
\end{tabular}

Remaining Life

a. Remaining Life Normal Load

The results of the cumulative ESAL that have been obtained then will be changed in the form of a percentage that shows a reduction in the remaining life of the road, for a decrease in the percentage of planned life can be seen in the table below:

Tabel 7. Remaining Life Normal Load

\begin{tabular}{|c|c|c|c|c|}
\hline Year Line & Year & ESAL & Cumulative ESAL & Remaining Life (\%) \\
\hline 0 & 2019 & 0 & 0 & 100 \\
\hline 1 & 2020 & 8.229 .766 & 8.229 .766 & 95,938 \\
\hline 2 & 2021 & 8.388 .355 & 16.618 .121 & 91,798 \\
\hline 3 & 2022 & 8.552 .415 & 25.170 .536 & 87,576 \\
\hline 4 & 2023 & 8.722 .223 & 33.892 .759 & 83,271 \\
\hline 5 & 2024 & 8.898 .072 & 42.790 .831 & 78,879 \\
\hline 6 & 2025 & 9.080 .274 & 51.871 .105 & 74,398 \\
\hline 7 & 2026 & 9.269 .157 & 61.140 .262 & 69,823 \\
\hline 8 & 2027 & 9.465 .069 & 70.605 .331 & 65,151 \\
\hline 9 & 2028 & 9.668 .378 & 80.273 .709 & 60,379 \\
\hline 10 & 2029 & 9.879 .476 & 90.153 .185 & 55,502 \\
\hline 11 & 2030 & 10.098 .776 & 100.251 .961 & 50,518 \\
\hline 12 & 2031 & 10.326 .717 & 110.578 .678 & 45,421 \\
\hline 13 & 2032 & 10.563 .763 & 121.142 .441 & 40,207 \\
\hline
\end{tabular}


E-ISSN: 2685-3272 | P-ISSN 1412-0860

\begin{tabular}{|c|c|c|c|c|}
\hline Year Line & Year & ESAL & Cumulative ESAL & Remaining Life (\%) \\
\hline 14 & 2033 & 10.810 .407 & 131.952 .848 & 34,871 \\
\hline 15 & 2034 & 11.067 .170 & 143.020 .018 & 29,408 \\
\hline 16 & 2035 & 11.334 .607 & 154.354 .625 & 23,814 \\
\hline 17 & 2036 & 11.613 .303 & 165.967 .928 & 18,082 \\
\hline 18 & 2037 & 11.903 .881 & 177.871 .809 & 12,206 \\
\hline 19 & 2038 & 12.207 .001 & 190.078 .810 & 6,181 \\
\hline 20 & 2039 & 12.523 .362 & 202.602 .172 & 0,000 \\
\hline
\end{tabular}

Source: Data in research, 2020

\section{a. Remaining Life Overload}

For the reduction in planned life, in this analysis the overload is used and compared with the remaining normal plan life, that it will be known how much influence of the overload on the Tangerang-Merak Toll Road. For the table of age reduction plans with overloading can be seen in the table below:

Tabel 3.7 Remaining Life Normal Load and Overload

\begin{tabular}{|c|c|c|c|c|c|}
\hline Year Line & Year & $\begin{array}{c}\text { ESAL } \\
\text { Overload }\end{array}$ & $\begin{array}{c}\text { Cumulative } \\
\text { ESAL Overload }\end{array}$ & $\begin{array}{c}\text { Cumulative } \\
\text { ESAL Normal } \\
\text { Load }\end{array}$ & Remaining LIfe (\%) \\
\hline 0 & 2019 & 0 & 0 & 0 & 100 \\
\hline 1 & 2020 & 11.165 .330 & 11.165 .330 & 8.229 .766 & 94,49 \\
\hline 2 & 2021 & 11.415 .050 & 22.580 .380 & 16.618 .121 & 88,85 \\
\hline 3 & 2022 & 11.674 .245 & 34.254 .625 & 25.170 .536 & 83,09 \\
\hline 4 & 2023 & 11.943 .405 & 46.198 .030 & 33.892 .759 & 77,20 \\
\hline 5 & 2024 & 12.223 .043 & 58.421 .073 & 42.790 .831 & 71,16 \\
\hline 6 & 2025 & 12.513 .705 & 70.934 .778 & 51.871 .105 & 64,99 \\
\hline 7 & 2026 & 12.815 .965 & 83.750 .743 & 61.140 .262 & 58,66 \\
\hline 8 & 2027 & 13.130 .435 & 96.881 .178 & 70.605 .331 & 52,18 \\
\hline 9 & 2028 & 13.457 .760 & 110.338 .938 & 80.273 .709 & 45,54 \\
\hline 10 & 2029 & 13.798 .621 & 124.137 .559 & 90.153 .185 & 38,73 \\
\hline 11 & 2030 & 14.153 .746 & 138.291 .305 & 100.251 .961 & 31,74 \\
\hline 12 & 2031 & 14.523 .896 & 152.815 .201 & 110.578 .678 & 24,57 \\
\hline 13 & 2032 & 14.909 .881 & 167.725 .082 & 121.142 .441 & 17,21 \\
\hline 14 & 2033 & 15.312 .565 & 183.037 .647 & 131.952 .848 & 9,66 \\
\hline 15 & 2034 & 15.732 .855 & 198.770 .502 & 143.020 .018 & 1,89 \\
\hline 16 & 2035 & 16.171 .712 & 214.942 .214 & 154.354 .625 & $-6,09$ \\
\hline 17 & 2036 & 16.630 .162 & 231.572 .376 & 165.967 .928 & $-14,299$ \\
\hline 18 & 2037 & 17.109 .282 & 248.681 .658 & 177.871 .809 & $-22,74$ \\
\hline 19 & 2038 & 17.610 .219 & 266.291 .877 & 190.078 .810 & $-31,435$ \\
\hline 20 & 2039 & 18.134 .191 & 284.426 .068 & 202.602 .172 & $-40,38$ \\
\hline & & & $504 r .52$ & \\
\hline
\end{tabular}

Source: Data in research, 2020

Comparison of Remaining Life

After knowing the decrease in the plan, both normal and overload, we can find out the difference between overload and not, we can present it in graphical form, the graph will show 
the difference. Firstly we look how much the increase that occurs each year, to find a graph of ESAL increase in both normal and overloads, can be seen in the graph below:

Figure 2. ESAL Cumulative Graph of Normal and Overload

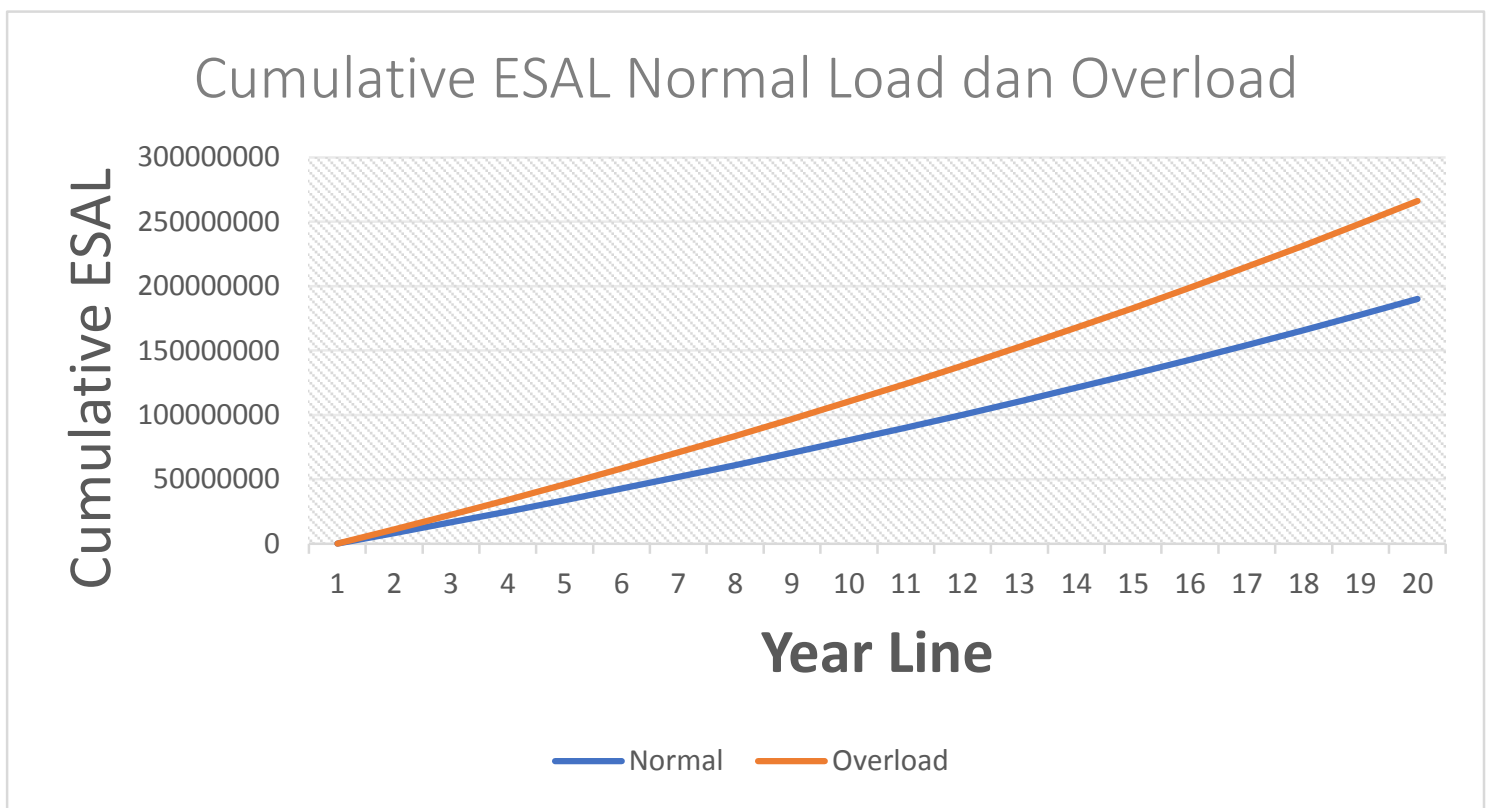

Source: Data in research, 2020

To find out how far the decline in plan life, we can use a decrease graph, so we can know the difference and how far the changes that occur are caused by overloading, to find out can be seen in the graph below:

Figure 3. Comparison Graph Between Overload and Normal

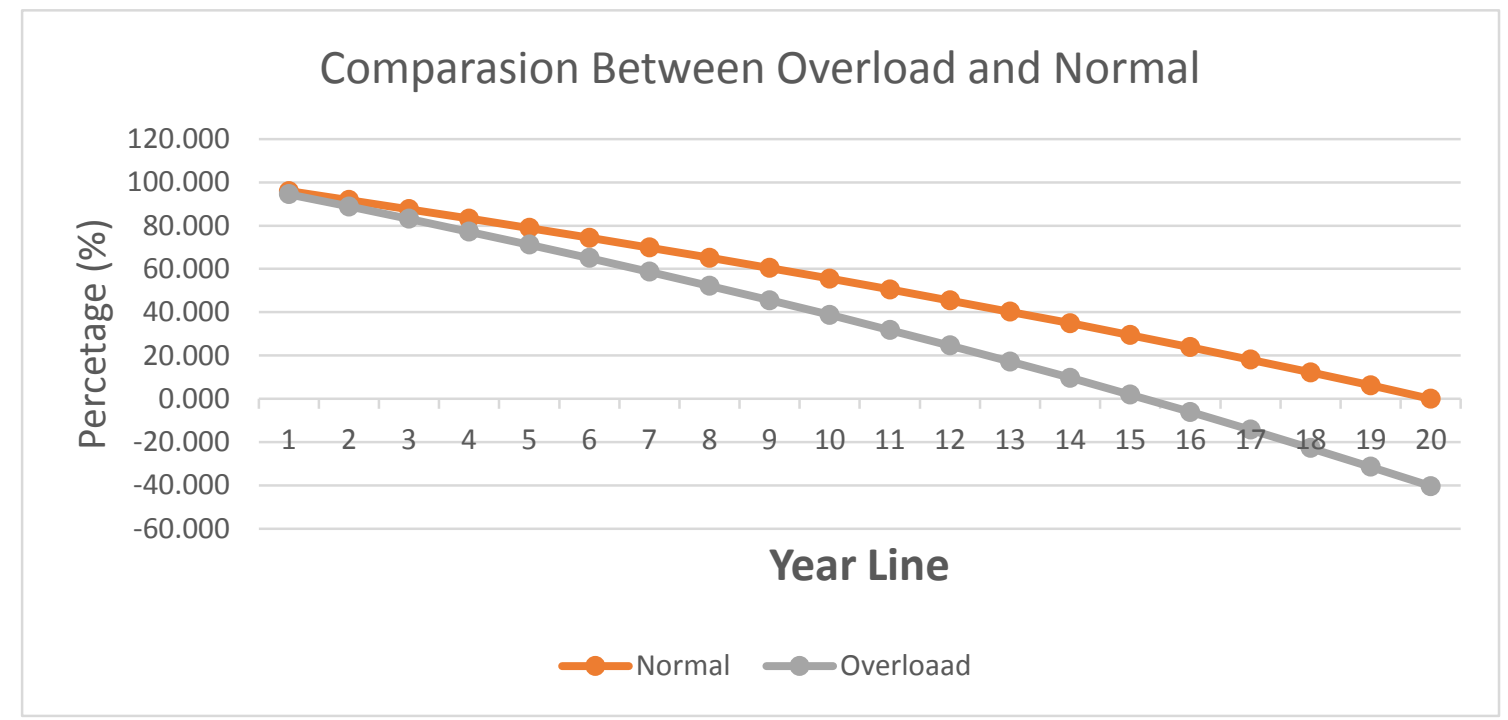

Source: Data in research, 2020

\section{CONCLUSION}

Based on the result of calculations and the analysis that have been described about the effect of overload on the age of the plan, it can be concluded as follows: 
a. From the analysis results of Vehicle Equivalent Numbers with overloading per configuration found an increase, namely for configurations $1-1$ to 0.0092 , configurations 1-2 to 2.1499, configurations 1-2.2 to 8.0444, configurations 1.2-2.2 to 6.7528 , configuration 1.2.2-2.2 becomes 11.7252, configuration 1.2.2-2.2.2 becomes 8,3279.

b. Based on the cumulative ESAL that was originally planned to receive a cumulative ESAL value of 202.602,172 in the 20th year, with the existence of overloaded vehicles the value can be achieved in the 15th year of the road life, the planned age has decreased the design life of the plan by 4 years 9 months that is, if it is used as a percentage, the overload that occurs on the Tangerang-Merak Toll Road KM 72 to KM 77 has decreased by $24 \%$.

\section{REFERENCES}

[1] AASHTO. (1993). Guide for Design of Pavement Structures. Washington DC.

[2] Anggista, R., Virgo Trisep Haris, \& Winayati. (2019). Analisis beban kendaraan terhadap derajat kerusakan dan umur sisa perkerasan (studi kasus : jalan lintas sumatera kecamatan payung sekaki). Pekanbaru: Universitas Lancang Kunig.

[3] Dinh, T. T. (2019). Overloading and selection of standard axel load in flexible pavement design. Hanoi: ThuyLoi University.

[4] Leo, S. (2012). Analisis Dampak Beban Overloading Kendaraan pada Struktur Rigid. Pekan Baru: Universitas Riau.

[5] Ojha, K. N. (2018). Overloading and Pavement Service Life ( A Case Study On Narayanghat-Mugling Road, Napal). Nepal: Tribhuwan University.

[6] Pais, J. C. (2013). Impact Of Traffic Overload on Road Pavement Performance. Journal of Transportation Engineering.

[7] Pemukiman, D., \& Departemen Pemukiman Dan Prasarana Wilayah. (2003). Perencanaan Perkerasan Jalan Beton. Pd T-14-2003.

[8] Raheel, M., Rawid Khan, \& Muhammad Taimur Khan. (2018). Impact of axle overload, asphalt pavement thickness and subgrade modulus on load equivalency factor using modified ESAL equation. Pakistan: University Of Engineering \& Technology Peshawar.

[9] Safitra, P. A., Theo K. Sendow, \& Sisca V. Pandey. (2019). Analisa Pengaruh Beban Berlebih Terhadap Umur Rencana (Studi Kasus: Ruas Jalan Manado-Bitung). Manado: Fakultas Teknik Universitas Sam Ratulangi.

[10] Saodang, H. (2005). Konstruksi Jalan Raya. Bandung: Nova.

[11] Suryawan, A. (2009). Perkerasan Jalan Beton Semen Portland (Rigid Pavement). Yogyakarta: Beta Offset. 